GEOGRAFICKÝ ČASOPIS / GEOGRAPHICAL JOURNAL 71 (2019) 2, 161-180

DOI: https://doi.org/10.31577/geogrcas.2019.71.2.09

\title{
EXPLAINING EMIGRATION PATTERNS IN ESTONIA, LITHUANIA, SLOVENIA AND SLOVAKIA
}

\author{
Andrej Př́ivara* \\ * Ekonomická univerzita v Bratislave, Národohospodárska fakulta, Katedra sociálneho rozvoja a práce, \\ Dolnozemská cesta 1,85235 Bratislava, andrej.privara@euba.sk
}

\begin{abstract}
Explaining emigration patterns in Estonia, Lithuania, Slovenia and Slovakia
The current paper contributes to the studies devoted to identifying the factors affecting emigration from CEE (Central and Eastern Europe), which are the EU member states to other EU states. In particular, the paper is focused on the factors affecting the emigration of the population from Estonia, Lithuania, Slovenia and Slovakia with Estonian, Lithuanian, Slovenian and Slovak citizenship respectively, to Germany as a destination country with the highest number of migrants among all the EU countries during the period $1998-2016$ with the use of fixed effects and OLS estimation methods. The paper contributes to the literature by an empirical analyses of the main economic determinants of emigration from Estonia, Lithuania, Slovenia and Slovakia to Germany.
\end{abstract}

Key words: emigration, migration flow, pull factors, push factors, gravity model, Central and Eastern Europe, Germany

\section{INTRODUCTION}

The necessity to understand the drivers of migration, in particular, in relation to why, where, when and how people tend to migrate, has become increasingly crucial to the current political debates for both origin and destination European countries. In light of this question, particular attention is paid to the migration process in Central and Eastern Europe (CEE). CEE has demonstrated an outstanding shift from the communist regime towards the market economy. An important component of the changes which accompanied that shift was the transition in the behaviour of migration. Until 1990, migration was extremely limited in all CEE countries. A leading form of the mobility of population was circulation, especially related to the purpose of work. International migration of the labour force was mainly enclosed within the CEE region, and strictly controlled by the governments. Only small-scale migration connected predominantly with family reunions or the "repatriation" of ethnic minorities and movements of workers was recorded. Since the early 1990s the situation has been changing considerably. The CEE region was characterized by an extreme rise in the complexity of migration forms, including labour force mobility through transit migration, and also the forced migration of asylum refugees. In many CEE countries immigrants of different status arrived in the region for the first time in the post-war history. Southern European countries have soundly established themselves as destination countries while CEE appeared as both a new source of migrant labour force, and to some extent also a destination region for non-European migrants.

The paper contributes to the studies devoted to identifying the factors affecting emigration from the CEE countries, which are the EU member states to other EU states. In particular, we focused on the factors affecting the emigration of the population from Estonia, Lithuania, Slovenia and Slovakia with Estonian, Lithuanian, Slovenian and Slovak citizenship respectively, to Germany as a destination country 
with the highest number of migrants among all the EU countries. The contribution of the paper refers to the empirical analyses of the main economic determinants of emigration from Estonia, Lithuania, Slovenia and Slovakia to Germany. We believe that the estimation of these determinants provides highly important insights for policy makers for shaping and carrying out targeted migration policies directed to the mitigation of population outflow. In our analysis of relevant emigration factors a gravity model has been employed. Results obtained helped to figure out the main determinants of emigration from the above mentioned CEE countries to Germany during the period $1998-2016$.

In the paper we present important findings from the literature, which refer to the factors affecting people's decisions to migrate, then we provide a description of the data and method we used for assessing the impact of different determinants on emigration from Estonia, Lithuania, Slovenia and Slovakia to Germany. At the end we discuss the results of the regression analysis and we emphasize the main conclusions.

\section{RELATED LITERATURE}

UN Food and Agriculture Organization (2019) defined migration as a "movement of people, either within a country or across international borders. It includes all kinds of movements, irrespective of the drivers, duration and voluntary/ involuntary nature. It encompasses economic migrants, distress migrants, internally displaced persons (IDPs), refugees and asylum seekers, returnees and people moving for other purposes, including for education and family reunification."

The core thesis underlying the reasons of migration says that migration is the result of push and pull factors (Tab. 1), such as employment and income opportunities, variances in standards of living, and in political freedom or repression (Massey 2005 and Castles et al. 2014). It is considered that individuals assess their life circumstances through a cost-benefit analysis and will move to another country in case the expected benefits are higher than the costs associated with movement to another country. Thus, the crucial factor upon which economists rely on is differences in income between different countries and regions (Beine et al. 2016). Massey et al. (1993, p. 432) argued that the "complex, multifaceted nature of migratory processes required a sophisticated theory that incorporates a variety of perspectives, levels and assumptions." There is still no well-established convergence across academic disciplines on a single model of migration theory. The strongest challenge to migration explorers is to organize hypothetically relevant factors into one comprehensible theoretical framework which would make it possible "to specify their interaction with each other in empirically testable form and thereby serve as a guide to future research" (Bodvarsson and Van den Berg 2013, p. 27).

Recent studies on migration have shown inspiring signs of convergence and attempts to bridge the gap between theory and empirics (Haas et al. 2018). Scholars across disciplines have shared the view, based on solid empirics, that people typically migrate for a variety of reasons, including economic, social, political, religious, psychological, emotional, cultural and environmental (Lilleør and Van den Broeck 2011, Bunea 2012, Crespo Cuaresma et al. 2014, Cummings et al. 2015, Török 2017 and van Ostaijen and Scholten 2018). People also need to obtain at least some form of capital, material, human or social, and they need to deal with structural components that enable or constrain their decisions. 
Tab. 1. The emigration decision

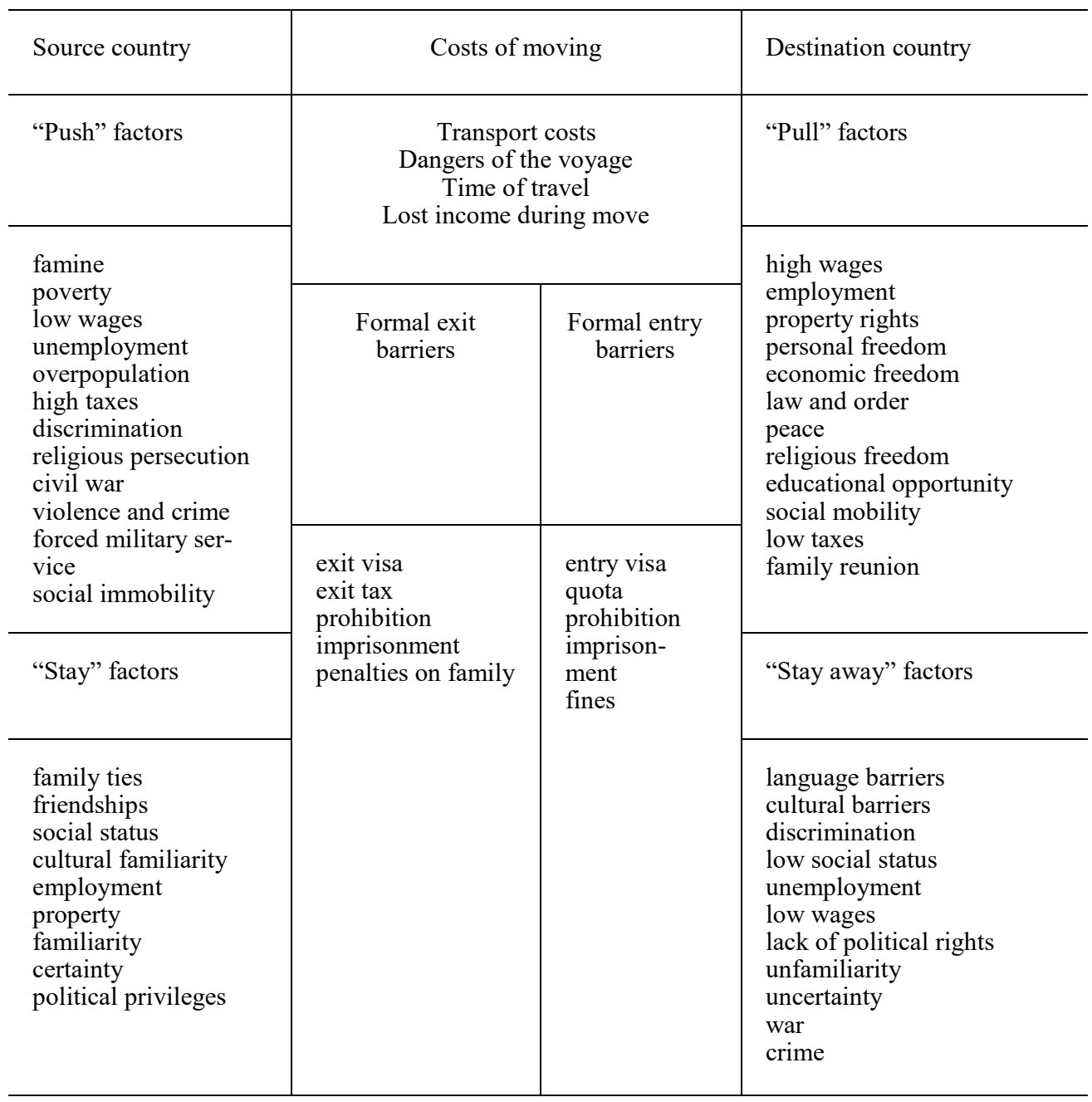

Source: (Bodvarsson and Van den Berg 2013).

After immigrants from a specific country have become established in a destination country, they frequently encourage friends or neighbors to follow them. Thus, this circumstance explains why specific destination cities and regions are prevalent for migrants from specific origin countries (Haller and Verwiebe 2016). It is much easier to cross the border of Hungary, Slovakia and Czechia and move to Austria, for instance, than to emigrate to Canada or Australia. Thus, the physical distance between origin and destination countries is also vital for the decision to migrate in the study of Belot and Ederveen (2012) and Adserà and Pytliková (2015). 
More specific indicators influencing migration can also be distinguished. In particular, Prada (2017) concluded that the increase in the rate of poverty for employed persons from 18 to 24 years of age, in the number of people living in households with a very low work intensity and in household consumption as a percentage of GDP, resulted in a reduction of net migration of the EU 28 during 2004 2013. On the other hand, an increase in the employment rate for the population of $15-24$ years of age and the old-age dependency ratio had a positive impact on net migration in the region during the same period.

Empirical studies also revealed that trade relations between the origin and destination countries also play an important role for migration decisions. Supportive evidence of the inverse relationship between unemployment and the attractiveness of the potential destination country was provided by Bertoli et al. (2016) and Beine et al. (2018). The outcome of the growth of the unemployment rate on the decision to migrate can be mitigated by the presence of unemployment benefits, as newly arrived immigrants are not eligible for unemployment advantages, therefore migration behavior could be more sensitive to changes in unemployment in the host country rather than in the source (Hudcovský et al. 2017).

When analyzing the influence of cultural change on migration behaviour, Lanati and Venturini (2018) used the data for 30 OECD host countries and 185 origin countries in the period 2004 - 2013 and assessed the impact of bilateral trade in cultural goods as a proxy for asymmetric and time-dependent cultural proximity. The authors supposed that the value of the bilateral exports of cultural goods reflects the affinity towards the destination's (exporter's) culture for the citizens in the country of origin (importer). They found that if there are pre-existing bilateral cultural ties, an increase in cultural affinity towards a potential destination stimulates bilateral migration flows towards that destination.

Findings from the literature confirm that the development of countries increases people's capabilities and incentives to migrate over larger distances, but it does not necessarily mean that migration will also increase. Migration decisions are also explained by a wide range of subjective factors, which broaden people's mental horizons, their perception of a "good" and "bad" life (Danaj et al. 2018 and Strielkowski et al. 2018). Such factors include, for example, media development, and often motivate people to move, for instance, from an agrarian lifestyle to a service sector in urban territories or abroad (Haas et al. 2018). While development in origin countries tends to enable people to migrate, the availability of concrete economic opportunities in destination countries generally determines whether prospective migrants will actually move. The implication for Europe is that patterns of future economic growth and labour market policies matter greatly in shaping future migration within, from and towards Europe.

Demographic factors, according to the World Bank and many researchers, also play an important role in the migration process. In particular, a high fertility rate has been indicated as one of the main factors affecting migration (Mansoor and Quillin 2006, Ramos and Suriñach 2013 and Coleman 2015).

When considering migration factors in Romania, Bunea (2012) indicated an educational offer to political variables of migration. A lack of basic health and education level was attributed to the economic pull factors of migration in the EU and its neighboring countries by Ramos and Suriñach (2013). Castles et al. (2014) concluded that good education, access to information and communication increase an 
individual's capabilities to emigrate. Jacques et al. (2016) indicated that "projections of migration flows by education level are potentially important." Wajdi et al. (2017, p. 318) researched migration in Indonesia and stated that "the level of educational attainment in a region can be expected to have a substantial effect on migration. The effect of an educational level is expected to be positive for both destination and origin. A region that has good higher-education facilities (senior high schools or universities) will attract people who are seeking higher education."

\section{DATA AND METHODS}

\section{Sample countries}

It should be mentioned that difficulties in conducting empirical research on migration frequently appear due to specific peculiarities of migration-related statistics. First, the availability of quality data is remarkably asymmetrical in terms of geographical coverage and skewed in terms of the forms of migration they are capable of capturing. Underlying issues of collecting proper migration statistics are the need of their systematization, gaps in statistics on short-term mobility, return flows and questionable data quality in most origin and host countries, which frequently lack the infrastructure for collecting data. In addition, despite some progress, greater international cooperation is needed (European Commission 2018).

As mentioned above there is a variety of factors affecting migration flows across the countries, which makes it problematic to build up one comprehensive theoretical model for assessing the causality between migration and those factors. Thus, in the current research we have evaluated the impact of a set of factors on migration outflows from several countries of the CEE region, in particular, from Estonia, Lithuania, Slovenia and Slovakia to Germany. The scope of the chosen countries is dictated by the availability of the data on annual migration flows for the long period. Germany was chosen as a destination country for our analysis, as for a long period of time it has been recognized as a third country after the USA and Saudi Arabia and the first the EU country which accepted the largest number of migrants according to the International Migration Report (UN 2017) - see Fig. 1.

In recent years the number of migrants in Germany has increased considerably demonstrating high employment quotas and a high degree of integration of migrants in the labour market (Tichelbäcker et al. 2018). The share of migrants with university degrees has increased. At the same time, the share of low-qualified migrants has declined with the remarkable exception of the first generation of migrants from Eastern Europe. However, for the total migrant population, employment quotas for migrants are still lower and unemployment rates are still higher if compared to the German population. Among the main obstacles to migration to Germany are the lack of German language skills and the recognition of foreign diplomas. The share of unemployed migrants with a better knowledge of German is lower than the share of unemployed migrants lacking language skills. Education received from abroad is assessed less on the German labour market if compared to educational attainment in Germany. The Federal Government adopted the Recognition Act, which entered into force on 1 April 2012 as a new instrument to secure the availability of skilled workers in Germany. All of the Länder legislation on recognition became effective on 1 July 2014 (Federal Ministry of education and 
Research 2017). However, it should be noted that there is a lack of well-established empirical evidence of the effects of the Act in the literature.
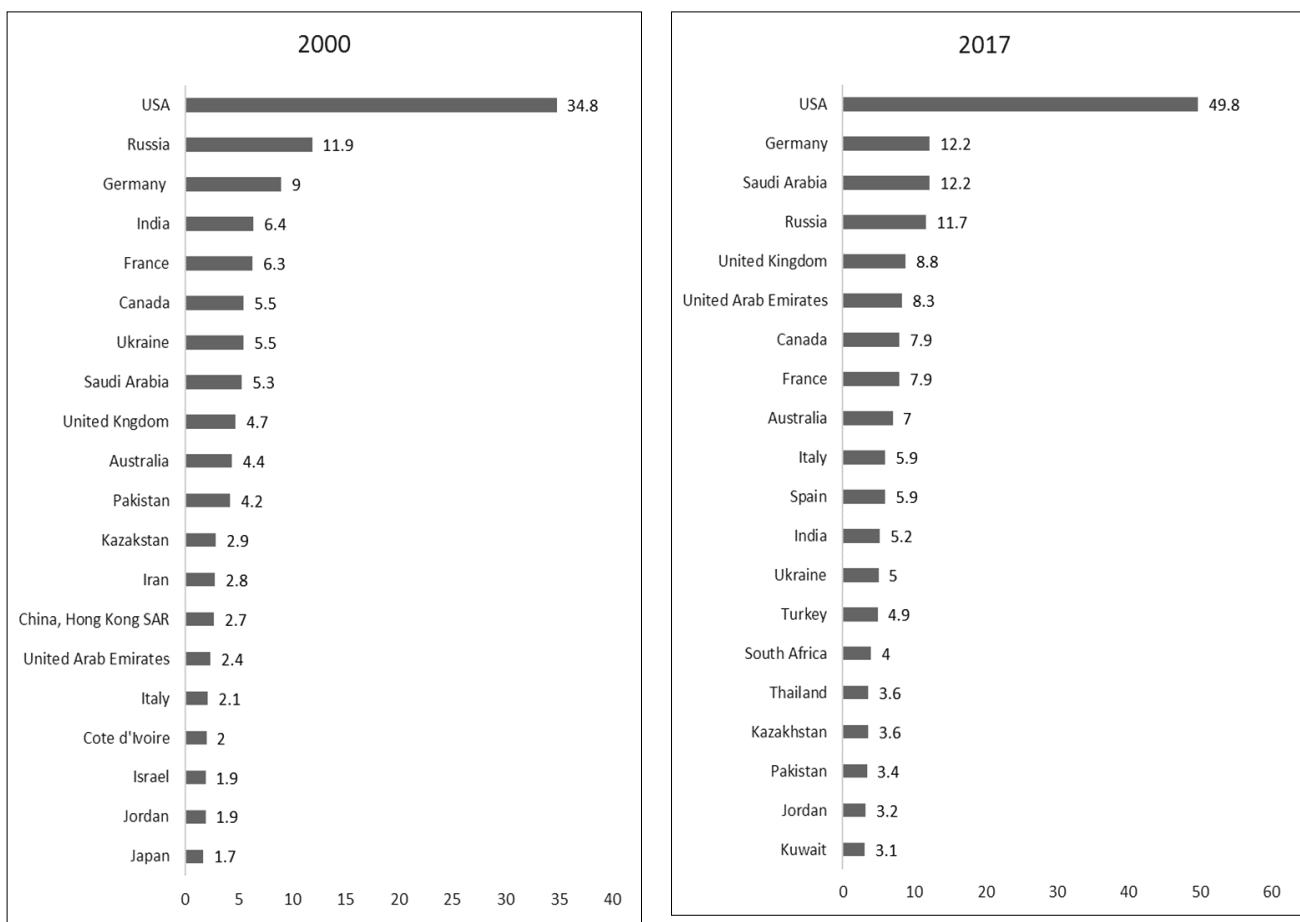

Fig. 1. Countries or areas hosting the largest number of international migrants (number of migrants, millions)

Source: International Migration Report (2017).

Other obstacles to residing in Germany have also had an impact. Different groups of migrants face different obstacles. For instance, migrants without any educational degree are to a greater extent dependent on informal networks. About $66 \%$ of low-skilled migrants specify to have found work through personal contacts such as family, friends or acquaintances vis-à-vis only $34 \%$ of high-skilled migrants. Migrants with a vocational or university degree rely more on private or public available vacancies in newspapers or online (Brücker 2014). However, again, there is still no well-established comparative view on obstacles, which low and high-skilled workers face when coming to the German labour market.

Thus, when the decision to migrate is taken, two above mentioned obstacles outline the extent to which in every specific case the migration will be successful. However, there are still many debates on the reasons why people decide to migrate to every specific country. It should be mentioned that such obstacles as mentioned could be also distinguished in other EU destination countries. But Germany is still the leader hosting the greatest number of migrants. Our research, thus, seeks to outline the main departure drivers which motivate people to move mainly to Germany. 


\section{Methods}

The literature distinguishes the most common approach for estimating migration drivers from historical data, in particular, the use of augmented gravity models, which provide multiple perspectives on international migration flows. First, they assess the character of the influence of push factors, the characteristics of the origin country, such as its demographic and economic conditions affecting migration outflows of the country. Second, they evaluate pull factors, which are features of the destination countries, which either attract or dampen the inflow of the population, such as their economic and labor market situation. Third, they incorporate bilateral factors like trade relations between the origin and destination countries. Finally, gravity models can easily be augmented to assess a variety of controls and policy variables. However, despite the number of advantages, which gravity models provide for estimating the influence of different variables, there are also difficulties when using them. First, it should be noted that the use of gravity models requires country pairs detailed data, including data on direct flows between the countries, which is not always available. Furthermore, the interpretation of gravity model outcomes from a policy perspective is frequently problematic due to questions related to data completeness and other factors which may have an influence on migration flows (Ramos and Suriñach, 2013).

The most commonly applied form of the gravity model of emigration is:

$$
M_{i j}=G \frac{P_{i}^{\alpha} \times P_{j}^{\beta}}{D_{i j}^{\gamma}},
$$

where $M_{i j}$ represents the number of people resident in area $j$ who at an earlier point in time resided in area $i ; P_{i}\left(P_{j}\right)$ represents the number of population of $i(j)$ usually measured at the beginning of the period over which migration is measured; $D_{i j}$ represents the measure of distance between $\mathrm{i}$ and $\mathrm{j} ; \alpha, \beta$ and $\gamma$ are parameters to be estimated and $G$ is a proportionality constant which depends on time dimension, geography and other factors. The recognition of this simple model was related to the ease with which it could be estimated by ordinary least squares (OLS) after a transformation into a logarithmic form (Jacques et al. 2016):

$$
\ln M_{i j}=\delta+\alpha \ln P_{i}+\beta \ln P_{j}-\gamma \ln D_{i j}+\varepsilon_{i j},
$$

where an error term has been added to the equation and the constant term $\ln G$ has been replaced by the parameter $\delta$.

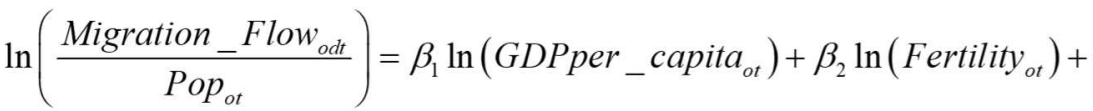

$$
\begin{aligned}
& \beta_{3} \ln \left(\text { Expenditure_education }_{\text {ot }}\right)+\gamma_{1} \ln \left(\text { Networks }_{\text {odt }-1}\right)+\gamma_{2} \ln \left({\text { Dis } \tan c e_{\text {od }}}\right)+ \\
& \gamma_{3} \ln \left(\text { Trade }_{\text {odt }-1}\right)+\delta_{1}\left(\text { GDP_per_capita_growth }_{d t}\right)+\gamma_{4} \ln \left(\text { Colonial_link }_{\text {od }}\right)+ \\
& \gamma_{5} \ln \left(\text { Comman_language } \text { od }_{1}\right)+\alpha_{0}+\alpha_{d}+\alpha_{t}+\varepsilon_{\text {odt }} \text {, }
\end{aligned}
$$

As a point of departure for developing our conceptual framework, we took the model for general international migration presented by European Commission (2018) in a report on international migration drivers: 
where the dependent variable is defined as the ratio of migration flow from origin $\mathrm{o}$, to destination $\mathrm{d}$, at time $\mathrm{t}$ to the population in the country of origin at time $\mathrm{t}$; GDP_per_capita is represented by GDP per capita in constant prices 2010; Fertility - total fertility rate; Expenditure_education - government expenditure on education; Networks - international migrant stocks; Distance - distance between capital cities of the origin and destination countries; Trade - trade openness; GDP per capita_growth - annual GDP per capita growth; Colonial link - colonial tie between the origin and destination countries; Common_language - common official language between the origin and the destination countries.

However, we seek to adopt the model (3) for the aim of our research by replacing some predictors presented in the equation above by those, which are more capable of explaining emigration flows from the origin CEE countries to Germany. Based on the above mentioned literature findings we developed the following model:

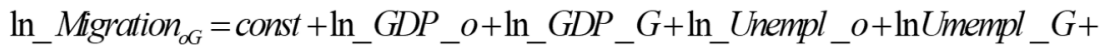

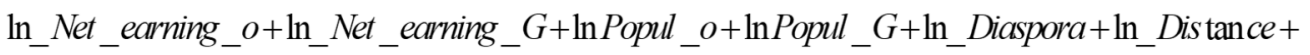
Exp_ech_o+Exp_ech_G+Enlargement_EU $+\operatorname{Re} m o v \_w o r k \_r e s t r+\varepsilon_{o G}$.

It should be noted that what is specifically important for the purpose of our research is to add a dummy variable on the EU enlargement in 2004. All four countries of the CEE included in our research joined the EU in 2004. Furthermore, on 1 May 2011 the restrictions on the "right to work in any Member State for citizens from the Czech Republic, Estonia, Latvia, Lithuania, Hungary, Poland, Slovenia and Slovakia" were removed (European Commission 2011). All employees from the countries which joined the EU in 2004 could "to take up employment freely in those Member States where labour market restrictions have been in place until the very end of the seven year transitional period ending April 30th 2011"(European Commission 2011). Thus, the dummy variable on the removal of work restrictions was also added to our regression model.

An indicator, which also substantially contributes to the increase in emigration flows, is the diaspora population of the origin countries of the CEE region living in Germany. Given the EU enlargement in 2004 and removal of work restrictions in 2011 it is vital, thus, to research the impact of the diaspora population from Estonia, Lithuania, Slovakia and Slovenia living in Germany, on the emigration flows from these countries to Germany.

We have not included the fertility rate to our model as the European countries are at the same stage of demographic development, the main tendency of which is the increase of old-age dependency accompanied by a low fertility rate which does not differ much among the EU member states.

\section{Data}

Our regression analysis employed the data available for the period during 1998 -2016 . The description of the variables is presented in the Tab. 2. 
Tab. 2. Description of variables

\begin{tabular}{|c|c|c|c|}
\hline Variable & Description & Source & $\begin{array}{c}\text { Expected sign } \\
\text { of the influence } \\
\text { on emigration flow }\end{array}$ \\
\hline $\begin{array}{l}\text { In_Migration } \\
\text { oG: } \\
\text { dependent variable }\end{array}$ & $\begin{array}{l}\text { Log of emigration flow from origin } \\
\text { country to Germany, thousands } \\
\text { persons }\end{array}$ & $\begin{array}{l}\text { Eurostat } \\
(2018 \mathrm{a})\end{array}$ & \\
\hline $\ln _{-} \mathrm{GDP}_{\mathrm{o}}$ & $\begin{array}{l}\text { Log of GDP at current prices, euro } \\
\text { per capita in origin country }\end{array}$ & $\begin{array}{l}\text { Eurostat } \\
(2019 a)\end{array}$ & - \\
\hline $\ln \_G D P_{G}$ & $\begin{array}{l}\text { Log of GDP at current prices, euro } \\
\text { per capita in Germany }\end{array}$ & $\begin{array}{l}\text { Eurostat } \\
(2019 a)\end{array}$ & + \\
\hline ln_Unempl & $\begin{array}{l}\text { Log of total unemployment rate } \\
\text { in origin country, thousands persons }\end{array}$ & $\begin{array}{l}\text { Eurostat } \\
(2019 b)\end{array}$ & + \\
\hline $\ln \_U n e m p l_{\mathrm{G}}$ & $\begin{array}{l}\text { Log of total unemployment rate } \\
\text { in Germany, thousands persons }\end{array}$ & $\begin{array}{l}\text { Eurostat } \\
(2019 b)\end{array}$ & - \\
\hline ln_Net_earning & $\begin{array}{l}\text { Log of annual net earnings in origin } \\
\text { country, euro }\end{array}$ & $\begin{array}{l}\text { Eurostat } \\
(2018 b)\end{array}$ & - \\
\hline $\ln \_$Net_earning $_{G}$ & $\begin{array}{l}\text { Log of annual net earnings in Germa- } \\
\text { ny, euro }\end{array}$ & $\begin{array}{l}\text { Eurostat } \\
(2018 b)\end{array}$ & + \\
\hline ln_Popul & $\begin{array}{l}\text { Log of total number of population } \\
\text { in origin country, thousands persons }\end{array}$ & $\begin{array}{l}\text { Eurostat } \\
(2019 c)\end{array}$ & + \\
\hline ln_Popul ${ }_{\mathrm{G}}$ & $\begin{array}{l}\text { Log of total number of population } \\
\text { in Germany, thousands persons }\end{array}$ & $\begin{array}{l}\text { Eurostat } \\
(2019 c)\end{array}$ & + \\
\hline ln_Diaspora & $\begin{array}{l}\text { The number of population with the } \\
\text { citizenship of origin country living } \\
\text { in Germany, thousands persons }\end{array}$ & $\begin{array}{l}\text { Eurostat } \\
(2019 c)\end{array}$ & + \\
\hline ln_Distance & $\begin{array}{l}\text { Log of distance between the capitals } \\
\text { of origin country and Germany } \\
\text { in kilometers }\end{array}$ & CEPII (2018) & - \\
\hline Exp_edu & $\begin{array}{l}\text { Expenditure on education as \% } \\
\text { of GDP or public expenditure } \\
\text { in origin country }\end{array}$ & $\begin{array}{l}\text { Eurostat } \\
(2018 c)\end{array}$ & + \\
\hline Exp_edu ${ }_{\mathrm{G}}$ & $\begin{array}{l}\text { Expenditure on education as \% } \\
\text { of GDP or public expenditure } \\
\text { in Germany }\end{array}$ & $\begin{array}{l}\text { Eurostat } \\
(2018 \mathrm{c})\end{array}$ & + \\
\hline Enlargement_EU & $\begin{array}{l}\text { Dummy variable indicating the EU } \\
\text { enlargement in } 2004(0,1)\end{array}$ & $\begin{array}{c}\text { European } \\
\text { Union (2019) }\end{array}$ & + \\
\hline Remov_work_restr & $\begin{array}{l}\text { Dummy variable on the removal } \\
\text { of work restrictions }\end{array}$ & $\begin{array}{l}\text { European } \\
\text { Commission } \\
(2011)\end{array}$ & + \\
\hline
\end{tabular}

Source: author.

\section{Limitations of research}

The limitations of our empirical strategy come from two issues. First, the linkages underlying the results are assumed to be interpreted as causal relationships. Reversal effects between emigration flows and predictors cannot be excluded. In particular, in our empirical research we used the data on unemployment, however, 
migration flows between the countries also impact unemployment rates. A second issue is related to the fact that the influence of other possible migration factors is not considered in our research due to the lack of the data or conceptual issues. For example, we did not investigate such push factor as wages in specific factors, family ties as a stay factor, family reunion as a pull factor and language barrier as a "stay away" factor.

Other limitations of current research are related to the complexity of assessing migration data itself. Whereas migration is more responsive to short-term economic influences than other demographic events, fast information on migration changes does not exist.

It is more proper to use monthly data, however, it is available in very few EU countries and, due to their rapid and primary character, does not always link to the annual figures that are published later. Furthermore, even in the case of the availability of monthly data on migration, it is not possible to conduct proper research as monthly data is not available for most of the other important indicators which have a significant on migration.

Additionally, it should be noted that data sources often disregard some groups of migrants or fail to record some events even if all the relevant groups are involved. When investigating time series, all breakdowns due to different reasons should be followed very cautiously. These reasons may be categorized into two groups: changes in administrative or legal measures, in particular, changes in the registration and regularization of illegal migrants, or changes in the statistical methodology, for instance, using new data sources and definitions (Herm and Poulain 2010). These breakdowns in series and artificial changes can easily appear to be changes in migration tendencies and distort the analysis of the influence of many economic variables.

\section{RESULTS}

We employed fixed effects and pooled OLS estimation methods. Table 3 shows summary statistics on the variables included in regression analysis, Tab. 4 presents the regression results of fixed effects estimation and pooled OLS. The differing group intercepts test, White test for heteroskedasticity and normality of residual test is presented in the Tab. 5. The collinearity test is presented in table 6 .

The differing group intercepts test (Tab. 5) with robust (HAC) standard errors adjustment has indicated that there are no fixed effects in analyzed sample countries and pooled OLS is a proper estimation method in terms of our research. The collinearity test (Tab. 6) has indicated a collinearity problem, as according to the well-established rule, the values of variance inflation factors should not be higher than 10.0. In order to address the problem when conducting OLS estimation, the OLS model 3 has been modified to model 4. 
Tab. 3. Summary Statistics

\begin{tabular}{|c|c|c|c|c|}
\hline Variable & Mean & Median & Minimum & Maximum \\
\hline 1_Migration & 6.3950 & 6.0523 & 4.5951 & 8.5943 \\
\hline 1_GDP_o & 9.1539 & 9.3147 & 7.9374 & 9.8782 \\
\hline 1_GDP_G & 10.313 & 10.3290 & 10.111 & 10.496 \\
\hline 1_Unempl_o & 4.8785 & 4.6151 & 3.4657 & 6.2226 \\
\hline 1_Unempl_G & 7.9925 & 8.0385 & 7.4810 & 8.4132 \\
\hline 1_Net_earning_o & 8.3913 & 8.4693 & 7.3692 & 9.0741 \\
\hline 1_Net_earning_G & 9.7736 & 9.7731 & 9.5858 & 9.9481 \\
\hline 1_Popul_o & 14.781 & 14.7080 & 14.0890 & 15.5070 \\
\hline 1_Popul_G & 18.220 & 18.2240 & 18.2000 & 18.2290 \\
\hline 1_Diaspora & 9.5240 & 9.8366 & 8.0624 & 10.7780 \\
\hline ln_Distance & 6.6378 & 6.6458 & 6.3154 & 6.9441 \\
\hline Exp_edu_o & 5.0222 & 5.1450 & 3.6100 & 6.7400 \\
\hline Exp_edu_G & 4.7206 & 4.6700 & 4.4300 & 5.0800 \\
\hline Enlargement_EU & 0.6842 & 1.0000 & 0.0000 & 1.0000 \\
\hline Remov_work_restr & 0.3158 & 0.0000 & 0.0000 & 1.0000 \\
\hline Variable & $5 \%$ Perc. & $95 \%$ Perc. & Std. Dev. & IQ range \\
\hline 1_Migration & 4.8921 & 8.2468 & 1.20200 & 2.38510 \\
\hline 1_GDP_o & 8.1887 & 9.8140 & 0.53363 & 0.79672 \\
\hline 1_GDP_G & 10.1110 & 10.496 & 0.11960 & 0.21796 \\
\hline 1_Unempl_o & 3.7316 & 6.1748 & 0.79564 & 1.43630 \\
\hline 1_Unempl_G & 7.4810 & 8.4132 & 0.26825 & 0.50415 \\
\hline 1_Net_earning_o & 7.4539 & 9.0510 & 0.44848 & 0.61238 \\
\hline 1_Net_earning_G & 9.5858 & 9.9481 & 0.10882 & 0.16672 \\
\hline 1_Popul_o & 14.0930 & 15.5040 & 0.52230 & 1.15490 \\
\hline 1_Popul_G & 18.2000 & 18.2290 & 0.00949 & 0.01516 \\
\hline 1_Diaspora & 8.1804 & 10.6040 & 0.77899 & 1.27500 \\
\hline ln_Distance & 6.3154 & 6.9441 & 0.22809 & 0.50206 \\
\hline Exp_edu_o & 3.8275 & 6.0080 & 0.72257 & 1.20920 \\
\hline Exp_edu_G & 4.4300 & 5.0800 & 0.22574 & 0.42455 \\
\hline Enlargement_EU & 0.0000 & 1.0000 & 0.46792 & 1.00000 \\
\hline Remov_work_restr & 0.0000 & 1.0000 & 0.46792 & 1.00000 \\
\hline
\end{tabular}

Source: author's statistical results. 
Tab. 4. Regression results

\begin{tabular}{|c|c|c|c|c|}
\hline Variables & $\begin{array}{c}\text { Model 1 } \\
\text { basic gravity } \\
\text { model } \\
\text { Fixed effects } \\
\text { RBS }\end{array}$ & $\begin{array}{l}\text { Model } 2 \\
\text { basic gravity } \\
\text { model } \\
\text { OLS }\end{array}$ & $\begin{array}{c}\text { Model } 3 \\
\text { modified basic } \\
\text { gravity model } \\
\text { OLS }\end{array}$ & $\begin{array}{c}\text { Model } 4 \\
\text { modified basic } \\
\text { gravity model } \\
\text { OLS }\end{array}$ \\
\hline \multicolumn{5}{|l|}{ Dependent variable: } \\
\hline 1_Migration constant & $\begin{array}{c}349.53 \\
(101576)\end{array}$ & $1390.49 *$ & $-99.18 * * *$ & $-99.33 * * *$ \\
\hline 1_GDP_o & -0.71 & $-2.55^{* * *}$ & $-5.28 * * *$ & $-4.89 * * *$ \\
\hline 1_GDP_G & $\begin{array}{c}(0.93) \\
4.45\end{array}$ & $\begin{array}{l}(0.72) \\
11.54\end{array}$ & $\begin{array}{l}(0.35) \\
13.68 * * *\end{array}$ & $\begin{array}{l}(0.34) \\
13.76^{* * *}\end{array}$ \\
\hline & $\begin{array}{l}(9.09) \\
(027)\end{array}$ & $\begin{array}{l}(8.79) \\
-0.71 * *\end{array}$ & ${ }_{-156 * * *}^{(2)}$ & $(1.22)$ \\
\hline 1_Unempi_o & $(0.23)$ & $(0.3)$ & $(0.21)$ & \\
\hline 1_Unempl_G & 1.2 & $2.4 * *$ & & $-1.25 * * *$ \\
\hline 1_Net_earning_o & 0.37 & $\begin{array}{l}(0.94) \\
-1.09\end{array}$ & & \\
\hline & $(0.53)$ & $(0.91)$ & & \\
\hline 1_Net_earning_G & $\begin{array}{c}2.43 \\
(11.7)\end{array}$ & $\begin{array}{c}4.02 \\
(11.14)\end{array}$ & & \\
\hline 1_Popul_o & $\begin{array}{l}3.5 \\
(3.7)\end{array}$ & $\begin{array}{c}0.24 \\
(1.12)\end{array}$ & & \\
\hline 1_Popul_G & $\begin{array}{l}-25.76 \\
(58.48)\end{array}$ & $\begin{array}{l}-85.82^{* *} \\
(40.4)\end{array}$ & & \\
\hline 1_Diaspora & $\begin{array}{c}0.06 \\
(1.22)\end{array}$ & $\begin{array}{l}1.44 * * * \\
(0.25)\end{array}$ & $\begin{array}{l}1.43 * * * \\
(0.15)\end{array}$ & \\
\hline 1_Distance & & $\begin{array}{l}3.14 \\
(2.43)\end{array}$ & & $\begin{array}{l}1.23 * * * \\
(0.14)\end{array}$ \\
\hline Exp_edu_o & $\begin{array}{l}-0.17 \\
(0.25)\end{array}$ & $\begin{array}{l}0.57 * * * \\
(0.17)\end{array}$ & $\begin{array}{l}0.7^{* * * *} \\
(0.16)\end{array}$ & \\
\hline Exp_edu_G & $\begin{array}{c}-0.02 \\
(1.1)\end{array}$ & $\begin{array}{c}-0.07 \\
(0.98)\end{array}$ & $\begin{array}{l}1.03 * \\
(0.51)\end{array}$ & $\begin{array}{l}0.89 * * * \\
(0.13)\end{array}$ \\
\hline Enlargement_EU & $\begin{array}{l}-0.08 \\
(0.35)\end{array}$ & $\begin{array}{c}-0.19 \\
(0.52)\end{array}$ & $\begin{array}{l}0.91 * * * \\
(2.5)\end{array}$ & \\
\hline Remov_work_restr & $\begin{array}{l}-0.3 \\
(1.53)\end{array}$ & $\begin{array}{c}-1.29 \\
(0.97)\end{array}$ & $\begin{array}{l}0.05 \\
(0.25)\end{array}$ & $\begin{array}{l}0.95 * * * \\
(0.25)\end{array}$ \\
\hline Observations & 49 & 49 & 49 & 49 \\
\hline Number of countries & 4 & 4 & 4 & 4 \\
\hline LSDV R-squared & 0.96 & & & \\
\hline Within R-squared & 0.7 & & & \\
\hline R-squared & & 0.94 & 0.89 & 0.85 \\
\hline Adjusted R-squared & & 0.92 & 0.86 & 0.83 \\
\hline
\end{tabular}

Source: author's calculations.

Note: 1_Distance was omitted due to exact collinearity when calculating the fixed effects estimation. Standard errors in parentheses. ${ }^{*} \mathrm{p}<0.10 ; * * \mathrm{p}<0.05 ; * * * \mathrm{p}<0.01$. RBS - robust standard errors. 
Tab. 5. Differing group intercepts test, White test for heteroskedasticity, normality of residual test

\begin{tabular}{lcccc}
\hline \multicolumn{1}{c}{ Tests/Models } & $\begin{array}{c}\text { Model 1 } \\
\text { basic gravity } \\
\text { model } \\
\text { Fixed effects } \\
\text { RBS }\end{array}$ & $\begin{array}{c}\text { Model 2 } \\
\text { basic gravity } \\
\text { model } \\
\text { OLS }\end{array}$ & $\begin{array}{c}\text { Model 3 } \\
\text { modified basic } \\
\text { gravity model } \\
\text { OLS }\end{array}$ & $\begin{array}{c}\text { Model 4 } \\
\text { modified basic } \\
\text { gravity model } \\
\text { OLS }\end{array}$ \\
\hline $\begin{array}{l}\text { Robust test for differing } \\
\text { group intercepts }\end{array}$ & 0.19 & & & \\
$\begin{array}{l}\text { Test statistic for White test } \\
\text { for heteroskedasticity }\end{array}$ & $(0.9)$ & & & \\
$\begin{array}{l}\text { Test statistic for normality } \\
\text { of residual test }\end{array}$ & & 23.39 & 46.07 & 27.09 \\
\hline
\end{tabular}

Source: author's statistical results.

Note: p-values are in parentheses, RBS - robust standard errors.

Tab. 6. Collinearity test: variance inflation factors

\begin{tabular}{lccc}
\hline Variables/Models & $\begin{array}{c}\text { Model 2 } \\
\text { basic gravity model } \\
\text { OLS }\end{array}$ & $\begin{array}{c}\text { Model 3 } \\
\text { modified basic gravity } \\
\text { model } \\
\text { OLS }\end{array}$ & $\begin{array}{c}\text { Model 4 } \\
\text { modified basic gravity } \\
\text { model } \\
\text { OLS }\end{array}$ \\
\hline 1_GDP_o & 49.968 & 9.103 & 8.152 \\
1_GDP_G & 250.480 & 10.611 & 4.517 \\
1_Unempl_o & 29.114 & 7.960 & 4.915 \\
1_Unempl_G & 21.021 & & \\
1_Net_earning_o & 61.985 & & \\
1_Net_earning_G & 372.155 & & \\
1_Popul_o & 107.323 & & \\
1_Popul_G & 66.767 & 3.494 & \\
1_Diaspora & 14.954 & & \\
1_Distance & 121.549 & 2.726 & \\
Exp_edu_o & 5.472 & 3.188 & \\
Exp_edu_G & 18.870 & 3.664 & \\
Enlargement_EU & 18.550 & 3.116 & \\
Remov_work_restr & 70.651 & & \\
\hline
\end{tabular}

Source: author's calculation

Test results on collinearity (Tab. 6) for OLS estimation have shown there is a collinearity problem in basic model (Model 2). Thus, we have modified the basic model and omitted some variables from Model 2. Model 3 demonstrates the impact of eight predictors indicating that six predictors, in particular, unemployment in an origin country, diaspora, expenditures on education in the origin country, enlargement of the EU in 2004, GDP of the origin country and GDP of Germany appeared to be significant, whereas, the removal of work restrictions in 2011 and expenditures on education in Germany appeared to be insignificant. Model 4 shows the same direction of the influence of all significant predictors from Model 3, indicating that two predictors - the removal of work restrictions in 2011 and expenditures on education in Germany - can serve as control variables. 
As expected, we have indicated a negative effect of the increase in GDP of the origin country and a positive influence of the increase in the GDP of Germany on the decision of the population with Estonian, Lithuanian, Slovenian and Slovak citizenship to migrate to Germany. This result confirms our assumption that a higher level of economic development in the origin country stimulates the population to stay in its home country and not move to other countries. However, the increase of the level of economic development of Germany attracts the population from analysed countries and causes it to migrate.

Our results have identified that an unemployment increase in the origin countries during analysed period of 1998 - 2016 associated with a decrease in emigration flows to Germany is not consistent with our assumptions. However, the literature findings have revealed the following reasons for that.

First, studies on the migration in the EU during crisis of 2008 show that the increase in unemployment rate in the EU countries, which was specifically noticeable during financial crisis of 2008 was negatively associated with migration for both nationals and non-nationals. According to an ILO report (Awad 2009) a strong negative relationship between unemployment and the level of non-national immigration has been found. Dobson et al. (2009) have also indicated a negative association for the emigration of non-nationals; the association between unemployment and emigration for nationals was also negative and more prominent. Skeldon (2010) states if economic growth slows down and jobs are lost, it is likely foreign migrants may no longer be needed and those migrants already in low-growth host economies may rationally be anticipated to return home.

The second reason as mentioned above may be behind the frequency of data on migration used in analysis. When researching the influence of the economic crises of 2008 on migration in the EU countries, Herm and Poulain (2012) have found that, nevertheless, growing unemployment according to assumptions should positively effect emigration, but in some cases the trends were the opposite. The authors have indicated that emigration to Sweden and the Netherlands did not rise, the level stayed slightly lower than before the crisis. In the other countries, only a very small increase was observed during the last months of 2008. The authors also reported there was "a large increase in the number of EU citizens emigrating from their home country (emigration of nationals) and immigrating to another EU member state (immigration of EU citizens) under favorable economic conditions in the pre-crisis period, and a comparable decrease during the economic crisis". However, the authors also emphasized that given that the crisis started in mid-2008, the annual figures for 2008 "are composite and the annual data could be misleading." An analysis of the monthly data for the EU countries showed that a monthly increase in unemployment rates when the crisis started was accompanied by a relatively immediate migration in response to that increase, at least for EU citizens.

Third, it is also vital to mention that substantial improvements in the quality of the data have been made according to adopted EU Regulation (European Commission 2007). However, these improvements comprised changes in data collection methods and definitions, causing breakdowns in the time series. Specifically, it is important to mention in terms of current research that, Germany revised its immigration figures for 2009 from 721,014 according to the national definition, to 346,216 in conformity with the EU-authorized definition (Herm and Poulain 2012). 
Thus, given the use of monthly data on migration in our research was not appropriate, the negative association between unemployment and emigration in our research we can attribute to all of the reasons mentioned above.

As expected, expenditures on education in origin countries had a positive influence on emigration. As mentioned above, the increase in expenditures on education may broaden people's "horizons" and ambitions to leave the origin country. However, the increase in expenditures in Germany appeared to be an insignificant predictor. Hence, we conclude that this pull factor of Germany turned not to be weaker than the level of economic development of the country.

The increase of diaspora population as expected had a positive influence on the migration of the migrants with Estonian, Lithuanian, Slovenian and Slovak citizenship to Germany.

The influence of the dummy variable on the EU enlargement in 2004 also met our assumptions and positively influenced migration. However, the removal of work restrictions in 2011 turned out to not have an impact on migration. However as mentioned by the European Commission (2011, p. ) "The Commission does not expect huge flows of workers from the EU-8 countries as many wanting to move to work in an EU-15 Member State have already done so." Thus, our results have confirmed this expectation.

\section{CONCLUSION}

The research was aimed at identifying the drivers of emigration of the population with Estonian, Lithuanian, Slovenian and Slovak citizenship from four CEE region countries: Estonia, Lithuania, Slovenia and Slovakia to Germany during $1998-2016$.

We have employed the fixed effects and pooled OLS estimation method. However, the robust test for differing group intercepts has revealed there are no fixed effects in the estimated model and the pooled OLS method appeared to be a proper estimation method in terms of our research.

We analysed the influence of fourteen variables on migration flows from the above mentioned countries to Germany. Due to the revealed collinearity problem, we omitted a number of variables. Our results have shown that, as was assumed, the diaspora population with Estonian, Lithuanian, Slovenian and Slovak citizenship living in Germany, expenditures on education in the origin countries, the EU enlargement in 2004 and the GDP in Germany were positively associated with migration from CEE countries during 1998 - 2016. However, the removal of work restrictions in 2011 did not have an impact on migration confirming that the EU enlargement had already a facilitating impact on migration.

Expenditures on education in Germany also did not have an impact on migration, which along with the significance of variable on the GDP value in Germany, identified that the economic development of Germany was a stronger pull factor for the migrated population of the CEE region during 1998 - 2016.

The negative association between GDP value in origin countries with migration confirmed our assumption that a higher level of economic development of the origin country stimulated the inhabitants to stay at their origin country. 
Unemployment in origin country was negatively associated with migration that was not consistent with our assumptions. The reasons for that we attribute to the following: first, the studies revealed the fact that in the EU countries in the periods of rising unemployment, in particular, as literature emphasized during crisis 2008, the population can less likely to migrate. If economic growth slows down and jobs are lost, it is likely foreign migrants may no longer be needed and those migrants already in low-growth host economies may rationally be anticipated to return home. Second reason may be behind the frequency of data on migration used in analysis. Monthly migration data are more proper, however, it is not always possible to employ them.

Third, the adopted EU Regulation in 2007, to improve the migration data quality has changed the methodology to assessing migration that caused the changes in figures, that in turn, could cause a distortion of the direction of the impact of unemployment on migration.

The current paper leaves at least two important avenues for future research. First, our analysis shed new light on the drivers of emigration from the CEE countries to Germany. Further research can be devoted to exploring the influence of other drivers, which were not considered in the current analysis. Second, a parallel motivating avenue for further research may be to research the emigration flows of other countries of the EU to Germany.

This paper is an output of VEGA research project no. 1/0001/16: "Present and prospective changes in employment and related processes in the context of meeting the objectives of the European Employment Strategy" and VEGA research project no. 1/0287/19 "Integration of immigrants in EU countries from the point of view of migration policies".

\section{REFERENCES}

ADSERÀ, A., PYTLIKOVÁ, M. (2015). The role of language in shaping international migration. The Economic Journal, 125(586), 49-81. DOI: https://doi.org/10.1111/ ecoj. 12231.

AWAD, I. (2009). The global economic crisis and migrant workers. Geneva (ILO).

BEINE, M., BERTOLI, S., FERNÁNDEZ-HUERTAS MORAGA, J. (2016). A practitioners' guide to gravity models of international migration. The World Economy, 39, 496-512. DOI: https://doi.org/10.1111/twec.12265.

BEINE, M., BOURGEON, P., BRICONGNE, J. C. (2018). Aggregate fluctuations and international migration. The Scandinavian Journal of Economics, 121, 117-152. DOI: https://doi.org/10.1111/sjoe.12258.

BELOT, M., EDERVEEN, S. (2012). Cultural barriers in migration between OECD countries. Journal of Population Economics, 25, 1077-1105. DOI: https://doi.org/10.1007/ s00148-011-0356-X.

BERTOLI, S., BRÜCKER, H., FERNÁNDEZ-HUERTAS MORAGA, J. (2016). The European crisis and migration to Germany. Regional Science and Urban Economics, 60, 61-72. DOI: https://doi.org/10.1016/j.regsciurbeco.2016.06.012.

BODVARSSON, O. B., Van den BERG, H., eds. (2013). The economics of immigration: theory and policy. New York (Springer).

BRÜCKER, H. (2014). Die IAB-SOEP-Migrationsstichprobe: Leben, lernen, arbeiten - wie es Migranten in Deutschland geht (Reasearch Report No. 21/2014), [Online], Available: https://www.econstor.eu/handle/10419/158442 [accessed 15 December 2018]. 
BUNEA, D. (2012). Modern gravity models of internal migration. The case of Romania. Theoretical and Applied Economics, 9, 127-144, [Online], Available: http:// store.ectap.ro/articole/714.pdf [accessed 15 December 2018].

CASTLES, S., de HAAS, H., MILLER, M. J., eds. (2014). The age of migration: international population movements in the modern world. Basingstoke (Palgrave Macmillan).

CEPII (2018). Gravity. CEPII, [Online], Available: http://www.cepii.fr/CEPII/en/ bdd modele/presentation.asp?id=8 [accessed 15 December 2018].

COLEMAN, D. (2015). Migrants and migration in Europe. International Encyclopedia of the Social \& Behavioral Sciences, 376-388. DOI: https://doi.org/10.1016/B978-0-08097086-8.31122-9.

CRESPO CUARESMA, J., LÁBAJ, M., PRUŽINSKÝ, P. (2014). Prospective ageing and economic growth in Europe. The Journal of the Economics of Ageing, 3, 50-57. DOI: https://doi.org/10.1016/j.jeoa.2014.05.003.

CUMMINGS, C., PACITTO, J., LAURO, D., FORESTI, M. (2015). Why people move: understanding the drivers and trends of migration to Europe (Working paper No. 430). London (Overseas Development Institute).

DANAJ, A., LAZÁNYI, K., BILAN, Y. (2018). Perceptions and implications of immigration in France - economic, social, political and cultural perspectives. Economics \& Sociology, 11, 226-247. DOI: https://doi.org/10.14254/2071-789X.2018/11-3/14.

DOBSON, J., LATHAM, A., SALT, J. (2009). On the move? Labour migration in times of recession (Policy network paper), [Online], Available: https://www.geog.ucl.ac.uk/ research/research-centres/migration-research-unit/publications/mru-publications/pdfs/ on the move.pdf [accessed 15 December 2018].

EUROPEĀN COMMISSION (2007). On community statistics on migration and international protection and repealing council regulation (EEC) No 311/76 on the compilation of statistics on foreign workers, [Online], Available: https://eur-lex.europa.eu/legalcontent/EN/TXT/?uri=CELEX\%3A32007R0862 [accessed 15 December 2018].

EUROPEAN COMMISSION (2011). Press release database, [Online], Available: http:// europa.eu/rapid/press-release IP-11-506 en.htm [accessed 15 December 2018].

EUROPEAN COMMISSION (2018). International migration drivers: a quantitative assessment of the structural factors shaping migration, [Online], Available: http:// publications.jrc.ec.europa.eu/repository/bitstream/JRC112622/ imd report final online.pdf [accessed 15 December 2018].

EUROPEAN ŪNION (2019). Further expansion, [Online], Available: https://europa.eu/ european-union/about-eu/history/2000-2009 en [accessed 15 December 2018].

EUROSTAT (2018a). Emigration by age group, sex and country of next usual residence, [Online], Available: http://appsso.eurostat.ec.europa.eu/nui/show.do?dataset $=$ migr emi3nxt\&lang=en [accessed 15 December 2018].

EUROSTAT (2018b). Annual net earnings, [Online], Available: http:// appsso.eurostat.ec.europa.eu/nui/show.do?dataset=earn nt net\&lang=en [accessed 15 December 2018].

EUROSTAT (2018c). Expenditure on education as \% of GDP or public expenditure. [Online], Available: http://appsso.eurostat.ec.europa.eu/nui/show.do?dataset $=$ educ figdp\&lang=en [accessed 15 December 2018].

EUR̄OSTAT (2019a) Main GDP aggregates per capita, [Online], Available: http:// appsso.eurostat.ec.europa.eu/nui/show.do?dataset=nama 10 pc\&lang=en [accessed 15 December 2018].

EUROSTAT (2019b) Unemployment by sex and age - annual average, [Online], Available: http://appsso.eurostat.ec.europa.eu/nui/submitViewTableAction.do [accessed 15 December 2018].

EUROSTAT (2019c) Population on 1 January by age group, sex and citizenship, [Online], Available: http://appsso.eurostat.ec.europa.eu/nui/show.do?dataset=migr_pop1ctz\& lang=en [accessed 15 December 2018].

FEDERAL MINISTRY OF EDUCATION AND RESEARCH. (2017). Recognition of foreign professional qualifications, [Online], Available: https://www.bmbf.de/en/ 
recognition-of-foreign-professional-qualifications-1413.html [accessed 15 December 2018].

HAAS, H. DE, VEZZOLI, S., SZCZEPANIKOVA, A., VAN CRIEKINGE, T. (2018). European migrations dynamics, drivers, and the role of policies. Luxembourg (Publications Office of the European Union). DOI:10.2760/168653.

HALLER, M., VERWIEBE, R. (2016). Central Europe as a space of transnational migration: An introduction to the contributions in this issue. Osterreichische Zeitschrift für Soziologie, 41, 361-371. DOI: https://doi.org/10.1007/s11614-016-0250-6.

HERM, A., POULAIN, M. (2010). International migration data as input for population projections. Joint Eurostat/UNECE Work Session on Demographic Projections, [Online], Available: https://www.unece.org/fileadmin/DAM/stats/documents/ece/ces/ ge.11/2010/wp.20.e.pdf [accessed 15 December 2018].

HERM, A., POULAIN, M. (2012). Economic crisis and international migration. What the EU data reveal?. REMI, 28, 145-169. DOI: https://doi.org/10.4000/remi.6171.

HUDCOVSKÝ, M., LÁBAJ, M., MORVAY, K. (2017). Employment growth and labour elasticity in V4 countries: structural decomposition analysis. Prague Economic Papers, 26, (4), 422-437. DOI: https://doi.org/10.18267/j.pep.623.

JACQUES, P., OMONIYI, A., MICHAEL, C., DAVID, M. (2016). The gravity model of migration: The successful comeback of an ageing superstar in regional science, [Online], Available: https://papers.ssrn.com/sol3/papers.cfm?abstract id=2864830\#\# [accessed 15 December 2018].

LANATI, M., VENTURINI, A. (2018). Cultural change and the migration choice, [Online], Available: http://ftp.iza.org/dp11415.pdf [accessed 15 December 2018].

LILLEØR, H. B., VAN DEN BROECK, K. (2011). Economic drivers of migration and climate change in LDCs. Global Environmental Change, 21, 70-81. DOI: https:// doi.org/10.1016/j.gloenvcha.2011.09.002.

MANSOOR, A., QUILLIN, B., eds. (2006). Migration and remittances: Eastern Europe and the former Soviet Union. Washington (The World Bank). DOI: https:// doi.org/10.1596/978-0-8213-6233-4.

MASSEY, D. S., eds. (2005). Worlds in motion: understanding international migration at the end of the millennium, International studies in demography. Oxford (Oxford University Press).

MASSEY, D. S., ARANGO, J., HUGO, G., KOUAOUCI, A., PELlEGRINO, A., TAYLOR, J. E. (1993). Theories of international migration: a review and appraisal. Population and Development Review, 19, 431-466. DOI: https://doi.org/10.2307/2938462.

PRADA, E. M. (2017). Migration and its determinants: an Europe 2020 perspective. Ovidius University Annals, Economic Sciences Series, 0(1), 231-236, [Online], Available: http://stec.univ-ovidius.ro/html/anale/ENG/2017/Section-III/20_v2.pdf [accessed 15 December 2018].

RAMOS, R., SURIÑACH, J. (2013). A gravity model of migration between ENC and EU. Journal of Economic and Social Geography, 108, 21-35. DOI: https://doi.org/10.1111/ tesg. 12195.

SKELDON, R. (2010). The current global economic crisis and migration: policies and practice in origin and destination, [Online], Available: http://www.sussex.ac.uk/Units/ SCMR/drc/publications/working papers/WP-T32.pdf [accessed 15 December 2018].

STRIELKOWSKI, W., RAUSSER, G., BILAN, Y., TSEVUKH, Y. (2018). Migrant remittances and their impact on the economic development of the Baltic States. Geographica Pannonica, 22. DOI: https://doi.org/10.5937/22-16988.

TICHELBÄCKER, T. W., COLETTO, D., FELLINI, I., QUASSOLI, F., REYNERI, E., FULLIN, G., DIMITRIADIS, I. (2018). Overview of contextual and institutional factors for migration, [Online], Available: http://gemm2020.eu/wp-content/uploads/2017/09/ Report-Overview-of-institutional-factors.pdf [accessed 15 December 2018].

TÖRÖK, I. (2017). Migration patterns and core-periphery relations from the Central and Eastern-European perspective. European Review, 25, 388-405. DOI: https:// doi.org/10.1017/S1062798717000059. 
UNITED NATIONS (2017). International migration report (No. ST/ESA/SER.A/404), [Online], Available: https://www.un.org/en/development/desa/population/migration/ publications/migrationreport/docs/MigrationReport2017_Highlights.pdf [accessed 15 December 2018].

VAN OSTAIJEN, M., SCHOLTEN, P., eds. (2018). Between mobility and migration: the consequences and governance of intra-European movement. In Between mobility and migration, pp. 1-17. DOI: https://doi.org/10.1007/978-3-319-77991-1_1.

WAJDI, N., ADIOETOMO, S. M., MULDER, C. H. (2017). Gravity models of interregional migration in Indonesia. Bulletin of Indonesian Economic Studies, 53, 309-332. DOI: https://doi.org/10.1080/00074918.2017.1298719.

$$
\text { Andrej Přivara }
$$

\section{VYSVETLENIE EMIGRAČNÝCH MODELOV V ESTÓNSKU, LITVE, SLOVINSKU A NA SLOVENSKU}

Príspevok sa svojím obsahovým zameraním zarad’uje k štúdiám orientovaným na identifikáciu faktorov ovplyvňujúcich emigráciu zo štátov strednej a východnej Európy (SVE) do iných štátov EÚ. Zamerali sme sa najmä na faktory ovplyvňujúce emigráciu obyvatel'stva z Estónska, Litvy, Slovinska a Slovenska s estónskym, litovským, slovinským a slovenským občianstvom do Nemecka ako ciel'ovej krajiny s najvyšším počtom migrantov zo všetkých krajín EÚ. SVE zaznamenala mimoriadny posun od komunistického režimu k trhovému hospodárstvu. Dôležitou súčast'ou transformácie, ktorá sprevádzala tento posun, boli aj zmeny v migračnom správaní. Do roku 1990 bola migrácia vo všetkých krajinách SVE vel'mi obmedzená. Od začiatku devätdesiatych rokov sa situácia značne mení. Región SVE sa vyznačuje extrémnym nárastom zložitosti migračných foriem. Krajiny južnej Európy sa etablovali ako ciel'ové krajiny, zatial' čo SVE sa javí ako nový zdroj pracovnej migrácie a do istej miery aj ako ciel'ový región pre neeurópskych migrantov. Príspevok poskytuje empirické analýzy hlavných ekonomických determinantov emigrácie z Estónska, Litvy, Slovinska a Slovenska do Nemecka.

Pri realizácii nášho výskumu sme vychádzali z gravitačného modelu medzinárodnej migrácie, ktorý sme aplikovali na uvedené krajiny v období rokov 1998 - 2016. Použili sme pritom fixné efekty a odhad pomocou metódy najmenších štvorcov. Robustný test pre rôzne skupiny odhalil, že neexistujú žiadne fixné efekty a metóda najmenších štvorcov sa javí ako správna metóda odhadu v zmysle nášho výskumu.

Naše výsledky ukázali (v súlade s našimi predpokladmi), že také premenné, akými sú populácie diaspór s estónskym, litovským, slovinským a slovenským občianstvom žijúce v Nemecku, výdavky na vzdelávanie v krajinách pôvodu migranta, rozširovanie EÚ v roku 2004 a HDP v Nemecku pozitívne korelovali s migráciou z krajín strednej Európy v rokoch 1998 - 2016. Odstránenie pracovných obmedzení v roku 2011 však nemalo dosah na migráciu a potvrdilo, že už samotné rozšírenie EÚ v roku 2004 malo na migráciu ul'ahčujúci vplyv. Výdavky na vzdelávanie v Nemecku tiež nemali vplyv na migráciu, zatial' čo význam d'alšej premennej, ktorou je hodnota HDP v Nemecku, potvrdzuje, že hospodársky vývoj Nemecka bol v rokoch 1998 - 2016 silnejším faktorom pre migráciu obyvatel'stva $\mathrm{v}$ regióne SVE. Negatívna korelácia medzi hodnotami HDP v krajinách pôvodu migranta a migráciou potvrdila náš predpoklad, že vyššia úroveň ekonomického rozvoja krajiny pôvodu podnietila jej obyvatel'ov $\mathrm{k}$ tomu, aby neemigrovali.

Nezamestnanost' $\mathrm{v}$ krajine pôvodu migranta negatívne korelovala $\mathrm{s}$ migráciou, čo síce nebolo v súlade s našimi predpokladmi, možno to však vysvetlit' nasledujúcimi skutočnost’ami:

Po prvé, štúdie odhalili, že v krajinách EÚ v období rastúcej nezamestnanosti (ako sa to prejavilo aj počas krízy v roku 2008), je pravdepodobnost' migrácie obyvatel'stva nižšia. Ak 
sa spomalí hospodársky rast a stratia pracovné miesta, je pravdepodobné, že zahraniční migranti už nebudú potrební a existuje reálny predpoklad, že tí migranti, ktorí sa už nachádzajú v ekonomikách s nízkym rastom, sa vrátia domov. Druhým možným dôvodom je frekvencia údajov o migrácii použitých v tejto analýze. Mesačné údaje o migrácii sú vhodnejšie. Nie je však vždy možné ich využit', pretože iné determinanty migrácie nie sú dostupné z údajov získaných na mesačnej báze. Po tretie, nariadenie EÚ prijaté v roku 2007 na zlepšenie kvality údajov o migrácii malo za následok zmenu metodiky posudzovania migrácie, ktorá spôsobila zmeny v číselných údajoch, čo tiež mohlo spôsobit' skreslenie odhadu súvislosti medzi nezamestnanost’ou v krajine pôvodu a jej emigračnými tokmi. 